\title{
COMMENTS
}

\section{The Secured Creditor's Right to Full Liquidation Value in Corporate Reorganization}

A corporation forced by business failure into a state of legal insolvency or inability to pay its debts as they mature may petition the federal bankruptcy court to enforce a plan of reorganization, or may be brought into the court by a petition filed by its major creditors, under chapter $\mathrm{X}^{1}$ or section $77^{2}$ of the Federal Bankruptcy Act. Corporate reorganizations, which readjust the debt and equity obligations of the insolvent corporation, essentially provide a substitute for a forced liquidation sale of the debtor corporation. ${ }^{3}$ It may be difficult or impossible to sell a large bankrupt enterprise intact, and a sale in lot or bulk at spot market prices, especially in hard times, is likely to bring disastrously little for distribution among creditors and other claimants. ${ }^{4}$ In order to preserve the business as an operating entity until business fortunes improve, and to salvage "going concern" value, the spot market is bypassed. A fictional reorganization value is computed, which is said to represent the fair or intrinsic value of the business, and investors are compensated for their claims in securities of the reorganized enterprise. ${ }^{5}$

Reorganization is primarily beneficial to junior creditors and equity interests, since they are protected from the adverse consequences of a forced sale at market prices. ${ }^{6}$ At the same time, however, the reorganization process is geared to the protection of senior and secured creditors. ${ }^{7}$ Although the secured creditor is denied his

111 U.S.C. $\$ \S 501-676$ (1970) (corporate reorganizations). Three or more creditors with an aggregate liquidated claim of at least $\$ 5,000$ may file a petition if the corporation has been adjudged bankrupt or has committed an act of bankruptcy or if all or most of its property is held by a receiver or by an indenture trustee or mortgagee after default or is subject to a pending foreclosure proceeding. $I d$. $\$ \S 526,531$.

211 U.S.C. $\$ 205$ (1970) (railroad reorganizations).

3 See Blum, The Law and Language of Corporate Reorganization, 17 U. CHI. L. REv. 565, 566 (1950) [hereinafter cited as Corporate Reorganization]; Blum, Full Priority and Full Compensation in Corporate Reorganizations: $A$ Reappraisal, 25 U. CHI. L. REV. 417, 419 (1958) [hereinafter cited as Full Compensation]; Rosenberg, Beyond Yale Express: Corporate Reorganization and the Secured Creditor's Rights of Reclamation, 123 U. PA. L. REv. 509 (1975).

- Corporate Reorganization, supra note 3, at 566-67.

5 See generally Full Compensation, supra note 3.

- Corporate Reorganization, supra note 3, at 566.

"In this comment, "secured creditor" will refer to a lender, seller, or other person in 
contractual right to a foreclosure sale upon the debtor corporation's default, if the reorganization is successful, he will receive in securities of the reorganized business the equitable equivalent of the value of the lien or claim surrendered. ${ }^{8}$ The absolute priority doctrine, which was enunciated by the Supreme Court prior to the modern bankruptcy statutes, ${ }^{9}$ and which governs today, ${ }^{10}$ insures further that the adjustment process results in participation by junior security holders in the reorganized enterprise only after seniors have been fully compensated."

Moreover, although the reorganization process is designed to avoid the consequences of a liquidation sale, the value of a lien is broadly defined by the contractual right of a secured creditor to foreclose upon the debtor's default. The bankruptcy courts, being subject to the fifth amendment proscription against the taking of private property "for public use, without just compensation," must preserve not only the priority of the senior creditors, but also the property interests represented by the liens. ${ }^{12} \mathrm{~A}$ secured creditor in reorganization, then, is entitled to receive the value obtainable through ordinary bankruptcy foreclosure proceedings, a value known as liquidation value..$^{13}$

whose favor there is a security interest. See UNIFORM CoMmercial CODE $\S \S-9-105(\mathrm{~m}), 9-301(3)$.

See Full Compensation, supra note 3, at 421, quoting Group of Institutional Investors v. Chicago, M., St. P. \& P. R.R., 318 U.S. 523, 565 (1943).

- Northern Pac. Ry. v. Boyd, 228 U.S. 482 (1913).

10 Consolidated Rock Prods. Co. v. Du Bois, 312 U.S. 510 (1941); Case v. Los Angeles Lumber Prods. Co., 308 U.S. 106 (1939); see, e.g., In re Spectrum Arena, Inc., 340 F. Supp. 767, 779-80 (E.D. Pa. 1971).

"See 6A W. Collier, Bankruptcy 11.06 (14th ed. 1972). The absolute priority doctrine only states a rule of priority for the allocation of the value of an enterprise among competing claimants. It does not directly determine the minimum amount of compensation to which a secured creditor is constitutionally entitled in a reorganization, which is the subject of this comment. See text and notes at notes 13-14 infra; cf. REPORT OF THE COMMISsION ON THE Bankruptcy Laws of the United States, H.R. Doc. No. 93-137, 93d Cong., 1st Sess. pt. 1 at 254, 258-59 (1973) (suggesting that value in excess of liquidation value should not be distributed under a strict priority rule). But see Blum \& Kaplan, The Absolute Priority Doctrine in Corporate Reorganizations, 41 U. CHI. L. REv. 651 (1974). See also Trost, Corporate Bankruptcy Reorganizations: For the Benefit of Creditors or Stockholders?, 21 U.C.L.A.L. REv. 540 (1970).

${ }_{12}$ A lien has been held to be "property" within the meaning of the fifth amendment. Armstrong v. United States, 364 U.S. 40, 44 (1960); Louisville Joint Stock Land Bank v. Radford, 295 U.S. 555, 589 (1935). In a similar context, the mortgagee is entitled in eminent domain proceedings to have the mortgage debt satisfied in full from the proceeds of the condemnation award before other parties with interests may participate. 2 P. NichoLs, THE LAW OF EMINENT DoMaIN $\$ 5.741$, at 5-203 (rev. 3d ed. 1974).

"Cf. Fleischmann \& Devine, Inc. v. Saul Wolfson Dry Goods Co., 299 F. 15 (1st Cir. 1924); In re Atlas Pipeline Corp., 92 S.E.C. 416 (1941). 
In most successful reorganizations, senior security holders will be fully compensated for the value of their claims under the absolute priority doctrine. But in cases in which the value of the reorganized corporation (or, if the reorganization fails, of the laterliquidated property) declines during the pendency of the proceedings to such an extent that the secured creditors' liquidation value is not fully compensated for, an unconstitutional taking of their property occurs. This long-recognized ultimate limit on the power of the reorganization court has been reaffirmed in general by the Bankruptcy Commission in its proposed new Bankruptcy Act. ${ }^{14}$

Nevertheless, courts supervising the bankruptcy reorganization process have in recent years taken an increasingly expansive view of their powers and have evidenced increasing disregard of the immutable right of a secured creditor to the liquidation value of his lien. One knowledgeable commentator has observed, on the basis of both reported and unreported court orders, that courts deliberately delay hearings in order to give a distressed debtor more time in "disputes whose resolution is potentially disastrous for the debtor," and sometimes even render decisions that "are almost certain of reversal but which serve a useful protective purpose in the meantime."15 In 1970, the Supreme Court gave impetus to this trend by its statement in the New Haven Inclusion Cases $^{16}$ that secured creditors who invested in a railroad or public utility had "assumed the risk that in any . . . reorganization the interests of the public would

Liquidation value, in general, refers to the highest price that could be realized, whether by bulk or lot bidding, at a foreclosure sale. Cf. In re Winthrop Mills, 109 F. Supp. 323 (D. Me. 1952). In the case of a large multistate corporation, troublesome issues may be encountered in calculating a hypothetical liquidation value, as attested by the litigation that reached the Supreme Court in the New Haven Inclusion Cases, 399 U.S. 392 (1970). However, the concept of liquidation value as the amount that would have been realized through an actual foreclosure and sale commenced as of the date specified was not questioned. Although the issue was not decided in New Haven, see 399 U.S. at 459-67, the concept of liquidation value in the case of an interstate railroad probably should include an allowance for the time required to obtain a certificate of "public convenience and necessity" for abandonment which is required by section 77(o) of the Bankruptcy Act, 11 U.S.C. \$ 205(o) (1970), and section 1(18) of the Interstate Commerce Act, 49 U.S.C. $§ 1$ (18) (1970); cf. In re Penn Cent. Transp. Co., 384 F. Supp. 895, 922 (Spec. Ct. 1974), motion for leave to file petition for writ of certiorari and/or mandamus and/or prohibition denied, 420 U.S. 922 (1975).

14 Report of the Commission on the Bankruptcy Laws, supra note 11, pt. 1, at 258-59; pt. 2, at 237 (note to proposed section 7-203).

15 Festersen, Equitable Powers in Bankruptcy Rehabilitation: Protection of the Debtor and the Doomsday Principle, 46 AM. BANKR. L. J. 311, 329 (1972). Festersen has also observed that "[t]he courts are becoming more . . . disposed to exercise their discretionary powers in favor of debtors and, accordingly, more forthright about doing so." Id. at 317.

Is 399 U.S. 392 (1970). 
be considered as well as theirs." 17 The case has been viewed by some as having changed the law applicable to railroad and corporate reorganizations in general. ${ }^{18}$

The theme of this comment is that the law has not been changed and that it should not be changed by the courts. The first part of the comment will examine the development of protections for secured creditors' property interests under the modern reorganization statutes. The second part will argue that the New Haven decision did not change these basic rules. Finally, the policies behind protection of secured creditors and the purposes of the reorganization statutes will be briefly reviewed in order to indicate how fundamentally the corporate reorganization process would be altered by a rule that failed to preserve the liquidation value of secured creditors' liens adequately during the pendency of reorganization proceedings.

\section{Constitutional Protection of Secured Creditors in Reorganization}

A. Judicial Definition of the Scope of Secured Creditors' Protected Rights: Liquidation Value

In Continental Illinois National Bank \& Trust Co. v. Chicago, Rock Island \& Pacific Railway Co. ${ }^{10}$ the Supreme Court considered an appeal from an injunction restraining the sale of bonds held by creditors as security for notes of the debtor railroad. The bondholders argued that if the railroad reorganization statute sanctioned the injunction, it violated the fifth amendment by depriving them of their right to sell the pledged collateral upon default. ${ }^{20}$ But the debt obligations were well secured; the face amount of the collateral was three times greater than the debt, ${ }^{21}$ and unless a drastic change in circumstances were to have occured, the lien could not have been impaired by the injunction..$^{22}$ In addition, the lower court had found that sale of the collateral would prevent the formulation and con-

${ }^{17}$ Id. at 492, quoting Reconstruction Finance Corp. v. Denver \& R.G.W.R.R., 328 U.S. $495,535-36$ (1946).

1* See Note, Takings and the Public Interest in Railroad Reorganization, 82 YALE L. J. 1004 (1973) [hereinafter cited as Yale NoTE]; Murphy, Restraint and Reimbursement: The Secured Creditor in Reorganization and Arrangement Proceedings, 30 Bus. LAw. 15, 16 \& n.9 (1974).

12 294 U.S. 648 (1935).

2a Id. at 651-52.

21 Id. at 658-59.

22 Id. at 681. 
summation of a plan of reorganization..$^{23}$ On these facts, the $\mathrm{Su}-$ preme Court affirmed the lower court's order enjoining foreclosure on the lien interest. ${ }^{24}$

The decision in Continental Bank is consistent with earlier Supreme Court opinions invalidating injunctions that stayed liquidation of unprofitable enterprises. In Brooks-Scanlon Co. v. Railroad Commission, ${ }^{25}$ a state commission sought to compel a corporation to continue operating an unprofitable logging railroad at a loss. Justice Holmes, writing the opinion for the Court, stated that even if the corporation could be taken as having "granted to the public an interest in the use of the railroad," it could "withdraw its grant by discontinuing the use when that use can be kept up only at a loss." ${ }^{26}$ This rule has been recognized as limiting modern federal bankruptcy statutes as well. ${ }^{27}$

Taken together, the result of Continental Bank and the rule of Brooks-Scanlon define the outer limits of secured creditor rights of foreclosure when the debtor is in reorganization. The creditor's foreclosure remedy may be suspended in the interest of reorganizing the debtor's financial structure when, as in Continental Bank, there is no danger to his lien interest. But it would be confiscatory within the meaning of the fifth amendment to prevent withdrawal of capital through foreclosure if continued operation only imposed a loss

See id. at 678 .

21 The possibility of lien impairment was quite remote in Continental Bank itself, but the Court addressed the question of impairment to secured creditors' interests generally, stating that "[a] claim that injurious consequences will result to the pledgee or the mortgagee may not, of course, be disregarded . . . but it presents a question addressed not to the power of the court but to its discretion." Id. at 677 . Unfortunately, this language has led some courts to misstate the holding in Continental Bank, so as to permit a stay of foreclosure without regard to the security position of the creditor. See, e.g., In re Penn Cent. Transp. Co., 384 F. Supp. 895, 933 (Spec. Ct. 1974), motion for leave to file petition for writ of certiorari and/or mandamus and/or prohibition denied, 420 U.S. 922 (1975) (emphasizing likelihood of reorganization and thus overlooking consequences if reorganization should fail and liquidation ensue); In re Penn Cent. Transp. Co., 454 F.2d 9, 12 (3d Cir. 1972). For a more correct reading of Continental Bank, see In re Penn Cent. Transp. Co., 494 F.2d 270, 279 (3d Cir.), cert. denied, 419 U.S. 883 (1974). Other courts have stated the view, consistent with Continental Bank but beyond its particular facts, that if a secured creditor is harmed by a stay of foreclosure he would have a claim for compensation. See In re New York, N.H. \& H.R.R., 147 F.2d 40, 48 (2d Cir.), cert. denied, 325 U.S. 884 (1945).

${ }^{25} 251$ U.S. 396 (1920). See also Railroad Comm'n v. Eastern Tex. R.R., 264 U.S. 79 (1924); Bullock v. Railroad Comm'n, 254 U.S. 513 (1921).

${ }^{26} 251$ U.S. at 399.

${ }^{27}$ Regional Rail Reorganization Act Cases, 419 U.S. 102, 122 (1974); In re Penn. Cent. Transp. Co., 384 F. Supp. 895, 918-19 (Spec. Ct. 1974), motion for leave to file petition for writ of certiorari and/or mandamus and/or prohibition denied, 420 U.S. 922 (1975). See generally YALE NOTE, supra note 18, at 1008-10. 
on the creditor, as indicated by Brooks-Scanlon.$^{28}$ Continental Bank does not precisely define the property right of a secured creditor that is protected by the fifth amendment, since its holding was only that an injunction that "in no way impairs the lien" is not unconstitutional. Other Supreme Court decisions, however, have considered more directly the kind of impairment that may constitute sufficient confiscation.

In Louisville Joint Stock Land Bank v. Radford ${ }^{28}$ and in Wright $v$. Vinton Branch of the Mountain Trust Bank, ${ }^{30}$ the Supreme Court recognized that the property right in a lien, for purposes of rehabilitation and reorganization proceedings, is its liquidation value at the inception of the reorganization proceedings. ${ }^{31}$ The Court ruled that the fifth amendment requires the protection of this value against erosion during the rehabilitation proceeding. ${ }^{32}$ Although these cases involved specialized rehabilitation statutes applying to bankrupt farmers, the courts have recognized them as applicable to corporate reorganizations as well..$^{33}$

In Radford, the constitutionality of the original Frazier-Lemke Act $^{34}$ was decided. The Act, passed by Congress during the Depression, provided alternatives to the foreclosure sale of mortgaged farm property for bankrupt farmers whose creditors would not agree to composition under the Bankruptcy Act. The bankrupt farmer was given the option of purchasing all or any part of the property at its then appraised value by making deferred installment payments over a period of six years, the deferred payments accumulating interest

${ }^{28}$ But difficult problems of proof are pointed up in this regard by the government's argument in the Regional Rail Reorganization Act Cases, 419 U.S. 102 (1974), that compelled continued operation of the Penn Central at a loss according to an income statement did not necessarily erode the security interests of secured creditors because there were offsetting increases in the value of other assets. Brief for United States as Appellants at 59-73. Contra, Brief for Appellees Connecticut Gen. Ins. Corp., at 44-47.

295 U.S. 555 (1935).

30 300 U.S. 440 (1937).

31 See text and notes at notes $39-44,51-56$ infra. The liquidation value of the lien is defined at note 13 supra. But see Rosenberg, supra note 3, at 521 n.43.

${ }^{32}$ See Louisville Joint Stock Land Bank v. Radford, 295 U.S. 555, 596-97 (1935).

3 See, e.g., Regional Rail Reorganization Act Cases, 419 U.S. 102, 154 (1974) quoting Wright v. Union Cent. Life Ins. Co., 311 U.S. 275 (1940), another Frazier-Lemke Act case, as describing a standard for protection of secured creditors applicable in railroad reorganizations; In re Penn Cent. Transp. Co., 494 F.2d 270, 278 (3d Cir.), cert. denied, 419 U.S. 883 (1974); In re Penn Cent. Transp. Co., 454 F.2d 9, 13 n.10 (3d Cir. 1972) citing the Radford and Mountain Trust Bank cases as applicable in chapter X proceedings. See also YALE NoTE, supra note 18, at 1012: "In Radford the Supreme Court clearly interred any notion that bankruptcy proceedings may strip creditors of the right ultimately to receive the value of their collateral." But see Rosenberg, supra note 3, at 520-22.

34 Act of June 28, 1934, ch. 869, \& 1, 48 Stat. 1289-91. 
at the annual rate of one percent. If the mortgagee refused to consent to the installment purchase plan, the bankrupt could require the bankruptcy court to stay all proceedings for five years, during which time he would remain in possession, under court supervision, provided only that he pay an annual reasonable rental to be distributed among the creditors. At any time during the five-year period, the bankrupt could discharge the debt by paying into court the original appraised value of the property, or its subsequently reappraised value if the secured creditor had demanded a reappraisal..$^{35}$ The Court held that the Act violated the fifth amendment, stating that the statutory scheme resulted in "the taking of substantive rights in specific property." 36

The Court first found the installment purchase alternative objectionable because it would "not confer upon the mortgagee the ordinary fruits of an immediate sale."' ${ }^{37}$ The bankrupt's promise to pay was a mere unsecured personal obligation, and there was also danger that the property might be less valuable to the mortgagee because of waste and the accumulation of unpaid senior claims such as taxes. ${ }^{38}$ Further, since interest on the deferred installment payments accumulated at only one percent annually, which was significantly less than the market rate, the sale would not be, in economic reality, at the appraised value. ${ }^{39}$

The alternative provided by the Act if the mortgagee did not consent to the installment purchase option was also found unconstitutional. ${ }^{40}$ One defect was the scheme's failure to guarantee that taxes and insurance would be paid during the period of up to five years during which the bankrupt would retain possession. ${ }^{41}$ of greater importance was the suspension of the mortgagee's right to sell to another buyer at a favorable price during the period of possession, combined with the right of the debtor to purchase the farm at a reappraised price, ${ }^{42}$ even if it was less than the originally appraised value.

The opinion listed five specific property rights that the FrazierLemke Act took from the mortgagee,${ }^{43}$ including the right to collect

${ }^{35}$ This was the construction accepted by the Court. See Louisville Joint Stock Land Bank v. Radford, 295 U.S. 555, 593 n.23 (1935).

${ }^{36} \mathrm{Id}$. at 590 .

37 Id. at 591 .

38 Id. at 591-92.

33 Id.

10 Id. at 592-93.

4 Id. at 593 .

${ }^{43}$ Id. Only the mortgagee could request reappraisal under this version of the Act.

13 The Court found the following rights under applicable state law: 
his debt through judicial sale and the right to determine when such sale would be held. Thus, the fundamental objection to the Act was that the equivalent of the position available to the mortgagee through bankruptcy foreclosure proceedings was not preserved to him in the Frazier-Lemke Act rehabilitation process. The procedures under the Act were unconstitutional because bankruptcy liquidation value was potentially diminished by the uncompensated accumulation of senior claims, depreciation in the value of the collateral, and deprivation of the use value of capital. ${ }^{44}$

In the Mountain Trust Bank $k^{45}$ case, the Supreme Court held the second Frazier-Lemke Act ${ }^{48}$ constitutional. The new Act eliminated

1. The right to retain the lien until the indebtedness thereby secured is paid.

2. The right to realize upon the security by a judicial public sale.

3. The right to determine when such sale shall be held, subject only to the discretion of the court.

4. The right to protect its interest in the property by bidding at such sale. . . .

5. The right to control meanwhile the property during the period of default, subject only to the discretion of the court, and to have the rents and profits collected Id. at 594-95.

by a receiver for the satisfaction of the debt.

"The Frazier-Lemke Act required the payment of rental while the bankrupt farmer remained in possession of the property after the mortgagee refused to consent to an installment sale. Since market rental would include compensation for the use value of capital, the Act effectively required the payment of interest on the capital invested by the mortgagee and frozen by the stay on foreclosure. The payment of such interest would be essential to the validity of any statutory deferral of foreclosure rights, as is strongly suggested by the Court's criticism of the Act's installment purchase option on the ground that it provided for the accumulation of interest at a rate below the market rate. Id. at 591-92. Similarly, the payment of rental, including an interest component, was essential to the Supreme Court's decision that the Minnesota Mortgage Moratorium Law, which stayed foreclosure and extended the period of redemption during the Depression was constitutional. Home Bldg. \& Loan Ass'n v. Blaisdell, 290 U.S. 398,425 (1934). Requiring the payment of post-petition interest preserves the full liquidation value of the secured creditor's lien by compensating him for alternative uses of capital foregone after the inception of the proceeding during which foreclosure is stayed. The rule in eminent domain also is that interest runs from the date of the condemnation until the award is actually paid, and this is described as a matter of strict constitutional right. See 3 P. NIcHoLs, supra note 12 , at $\$ 8.63$.

In reorganization, however, the rule seems to be that interest accrues on secured claims during the pendency of the proceedings only if the value of the collateral exceeds the unpaid balance of the debt, if the collateral produces income, or if the estate proves sufficient to cover accumulated interest. In re Penn. Cent. Transp. Co., 454 F.2d 9, 16 (3d Cir. 1972); 3A W. Collier, supra note 11, \63.16; 6A W. ColuIER, id., $\uparrow 9.08$, at 201; Blum \& Kaplan, supra note 11 , at 682 . This rule is consistent with the concept of reorganization as a delayed substitute for liquidation, but is arguably inconsistent with the Radford rule in failing to recognize that a secured creditor's property right in a lien is measured by the full value of the right to commence foreclosure proceedings at the inception of the reorganization, including interest that could be earned on the capital in alternative uses. The Radford and Blaisdell decisions did not consider or rest upon whether the collateral produced income or whether its value exceeded the amount of the indebtedness.

is Wright v. Vinton Branch of the Mountain Trust Bank, 300 U.S. 440 (1935).

4 Act of Aug. 28, 1935, ch. 792, § 6, 49 Stat. 943-45. 
the installment purchase option, reduced the maximum stay of proceedings from five years to three, and required a semi-annual payment of rent based on "rental value, net income, and earning capacity of the property" during the period of possession, which was to be used first for taxes and upkeep. ${ }^{47}$ The bankruptcy court was given discretion to order interim payments on the principal and sale of nonexempt property. ${ }^{48}$ Finally, the bankrupt farmer as well as the creditor was given the option of demanding reappraisal of the property, after which he could satisfy the debt by paying the reappraised value. ${ }^{49}$

The main attack on the amended statute was that the secured creditor's right "to determine when a . . . [judicial] sale [was to] be held, subject only to the discretion of the court"50 was effectively denied by the three-year stay. ${ }^{51}$ But the Court construed the new Act as granting the debtor only a limited right to possession by implicitly empowering the supervising court to order an earlier sale. ${ }^{52}$ If it became apparent, for example, that the debtor could not refinance himself within the three-year period, the court could exercise its "broad power to curtail the stay for the protection of the mortgagee." ${ }^{53}$ In addition, semi-annual rental payments were required and could be supplemented by payments on the principal if, in the court's discretion, it was deemed necessary to "protect the creditors from loss." 54

As thus construed, the Act provided a high degree of protection for the mortgagee's liquidation value. ${ }^{55}$ The Court emphasized throughout its opinion in Mountain Trust Bank that the supervising court in a Frazier-Lemke Act proceeding had broad discretionary power, essential to the Supreme Court's conclusion that the Act was constitutional, to prevent the impairment of the mortgagee's lien by any loss in the value of the security. ${ }^{56}$ As a matter of doctrine, then,

"Id., 49 Stat. 944.

${ }^{18}$ Id.

${ }^{4} I d$.

so 300 U.S. at 460. See Louisville Joint Stock Land Bank v. Radford, 295 U.S. 555, 594 (1935).

51300 U.S. at 460.

52 Id. at $464 \&$ n.9.

53 Id. at 464 .

${ }^{34}$ Id. at 461 .

${ }^{55}$ In Wright v. Union Cent. Life Ins. Co., 311 U.S. 273 (1940), the Court, while considering another aspect of Frazier-Lemke Act proceedings, noted that the Act provided safeguards "to protect the rights of secured creditors, throughout the proceedings, to the extent of the value of the property." Id. at 278.

${ }^{\text {s6 }} \mathrm{See} 300$ U.S. at $458 \mathrm{n} .2,461-62,464$. The Court found a "careful intention to leave the 
the Court reaffirmed Radford in requiring protection of liquidation value. ${ }^{57}$ This proposition-that a secured creditor is constitutionally entitled to the liquidation value of his collateral-has never been abandoned by the Supreme Court ${ }^{58}$ and has been a fundamental referent for congressional advisers ${ }^{59}$ and for leading commentators. ${ }^{60}$

\section{B. Preserving Liquidation Value During Reorganization}

The financial needs of a corporate debtor are often great and the reorganization court is given broad powers to meet those needs in the interest of successful reorganization. ${ }^{61}$ The court has power to stay all enforcement of liens, whether by foreclosure or self-help..$^{62}$ In order to obtain operating funds, the court may authorize issuance of trustee certificates having priority over existing secured and nonsecured obligations..$^{63}$ It may use cash collateral derived from the sale of property that is the subject of a lien, ${ }^{64}$ and may order turnover of such cash proceeds if they are in the hands of indenture trustees. ${ }^{65}$ But the question of an unconstitutional taking of property

lien wholly unimpaired" underlying Congress's amendments to the original Act. Id. at 458 n.2.

57 The opinion contains ambiguous language that might be taken as permitting some impairment of the lien: "[The question] is whether the legislation modifies the secured creditor's rights, remedial or substantive, to such an extent as to deny the due process of law guaranteed by the Fifth Amendment. A court of bankruptcy may affect the interests of lien holders in many ways. . . ."Id. at 470 . But the examples cited by the Court to illustrate permissible modification of lien interests indicate that liquidation value must still be preserved. The first is the power of a bankruptcy court to marshall liens and to transfer the rights of lien holders from collateral to proceeds after the collateral is sold. Id. But it is firmly established that such power may not be exercised to the prejudice of the senior mortgage. G. Osborne, HandBook ON THE LaW of MorTGaGes $\$ 286$ (2d ed. 1970); see Louisville Joint Stock Land Bank v. Radford, 295 U.S. 555, 584 (1935); Continental Supply Co. v. Marshall, 152 F.2d. 300, 308 (10th Cir. 1945), cert. denied, 327 U.S. 803 (1946). The other example given is the power to enjoin the sale of collateral in a reorganization proceeding, but the cited authority, Continental Ill. Nat'l Bank \& Trust Co. v. Chicago, R.I. \& P. Ry., 294 U.S. 648 (1935), itself dealt with a situation for which the lien was fully protected by the excess value of the collateral. See text and notes at notes 19-22 supra.

5s See text and notes at notes 92-104 infra.

3) "A benchmark in determining the adequacy of protection is the liquidation value of the collateral at the date of the petition." REPORT OF THE COMM'N ON THE BANKRUPTCY LAws, supra note 11 , pt. 2 , at 237 .

${ }^{60}$ See Rosenberg, supra note 3, at 524-25; Trost, supra note 11, at 550-51.

"See generally $6 \mathrm{~W}$. Collier, supra note 11, ๆף 3.03, 3.05, 3.09, 3.10; Note, Interim Financing Through Use of the Turnover Power in Railroad Reorganizations, 71 YALE L.J. 1553 (1962).

${ }^{62}$ Bankruptcy Act $\$ 113,11$ U.S.C. $\$ 513$ (1970). A complete discussion of a chapter X court's power to stay execution of liens is found in Murphy, supra note 18, at 29-32.

w Bankruptcy Act § 116(2), 11 U.S.C. § 516(2) (1970).

"Id. $\$ 77,11$ U.S.C. $\$ 205(\mathrm{o})(1970)$.

is Id. $\S 257,11$ U.S.C. $\S 657$ (1970). 
may arise in the exercise of these powers if the security position of creditors is thereby diminished. The courts, however, have developed two tests designed to insure that secured creditors' property rights in the liquidation value of their liens are protected against being taken in violation of the fifth amendment.

In In re Third Ave. Transit Corp. ${ }^{86}$ the Second Circuit considered a petition by trustees of a bankrupt bus and trolley company to use proceeds from the sale of mortgaged properties, in the hands of the indenture trustee pursuant to contract, to meet the working capital or operating needs of the business. In reversing approval of the petition by the lower court, Judge Frank stated rules intended to permit such use of collateral only in the "most extraordinary circumstances." ${ }^{67} \mathrm{He}$ said that the court should permit a turnover of funds only if they could not be obtained on reasonable terms by other means and only if it were shown by the clearest evidence that it was highly likely that the debtor could be reorganized within a reasonable time and that "the secured creditors whose security is being compulsorily loaned will not be injured." 68

A similar doctrine has been developed to deal with petitions seeking the use of proceeds to make improvements and betterments to property subject to a lien. In Reconstruction Finance Corp. $v$. Kaplan, ${ }^{69}$ the court permitted use of cash collateral to prepare deteriorating inventory for sale, with the creditor's lien attaching to the proceeds. ${ }^{70}$ The court was influenced by the fact that the debts of the bankrupt were well secured, ${ }^{71}$ that a fair, equitable and feasible plan of reorganization had been filed in the court, ${ }^{72}$ and that the creditor would not be damaged by the action. ${ }^{73}$ The test applied in the Kaplan case was recently rearticulated by the Third Circuit in Central Railroad Co. v. Manufacturers Hanover Trust Co. ${ }^{74}$ (the Jersey Central case). The court contrasted the Third Ave. test for permitting the use of collateral for operating expenses, which the case actually involved, ${ }^{75}$ with the test for expenditures adding to or improving the capital of the debtor, which requires findings that

${ }^{86} 198$ F.2d 703 (2d Cir. 1952).

${ }^{67}$ Id. at 706.

${ }^{68} \mathrm{Id}$. at 707 .

68 185 F.2d 791 (1st Cir. 1950).

${ }^{70}$ Id. at 797-98; cf. Harding v. Stichman, 240 F.2d 289 (2d Cir. 1957).

7185 F.2d at 793, 797.

72 Id. at 793.

73 Id. at 793-94.

${ }^{74} 421$ F.2d 604 (3d Cir.), cert. denied, 398 U.S. 949 (1970).

${ }^{75}$ See id. at 606-07 \& n.6. The expenditures were for removal of a damaged railroad drawbridge that was in danger of collapsing. 
"funds are presently needed and cannot be obtained elsewhere ... that reorganization is probably feasible, that the money . . . expended for additions and betterments will materially contribute to the possibility of successful reorganization . . . and that the interests of the bondholders are not thereby prejudiced."76

The test for additions to capital stock is justifiably less restrictive than the test for expenditures for operating needs because additions to capital stock can continue to secure the creditors' claims. For example, cash expended for improvement of a freight yard certainly makes the mortgage holders' security less liquid, but as long as the value of their lien on the freight yard property exceeds the indebtedness, plus interest, their fifth amendment property right is protected. ${ }^{77}$ Although both tests require a finding that secured creditors' rights are not prejudiced, the statement of the "additions or betterments" test in Jersey Central includes within that requirement a determination that the property subject to lien will be worth no less after the conversion than before. Under Third Ave., by contrast, there must be a firm prediction that the operating expenditure from existing capital will not bring the value of property subject to lien below the amount of the secured creditors' claims. ${ }^{78}$

These tests focus on the same elements that the Supreme Court identified as significant in Continental Bank: first, the essentiality of the challenged action to a successful reorganization, and second, the assurance that secured creditors' property rights will be respected. Taken together, Continental Bank and the Third Ave. and Jersey Central cases indicate that a creditor's foreclosure action may be suspended and his security position diminished in the interest of reorganization, provided that the requirements of Radford and Mountain Trust Bank are met. Although the Third Ave. and Jersey Central tests depend, as does Mountain Trust Bank, ${ }^{79}$ upon the court's judgment as to when an action will impair a secured creditor's lien, the rule remains that the liquidation value of the lien must not be impaired.

"Id. at 606 .

$"$ See In re Penn Cent. Transp. Co., 474 F.2d 832 (3d Cir. 1973) ("Selkirk Yard" case).

77 See In re Penn Cent. Transp. Co., 494 F.2d 270, 276 (3d Cir.), cert. denied, 419 U.S. 883 (1974); cf. In re Boston \& Maine Corp., 484 F.2d 369 (1st Cir. 1973) (the facts indicated no threat to bondholders); In re Penn Cent. Transp. Co., 474 F.2d 832 (3d Cir. 1973) ("Selkirk Yard" case); In re Penn Cent. Transp. Co., 468 F.2d 1222 (3d Cir. 1972) ("Mortgage Release" cases); In re Penn Cent. Transp. Co., 454 F.2d 9 (3d Cir. 1972).

"See text and notes at notes 51-56 supra. 


\section{The Role of the Public Interest in Corporate Reorganization}

The New Haven Inclusion Cases, ${ }^{80}$ decided by the Supreme Court in 1970, contain language that recently has led the special railroad reorganization court, ${ }^{81}$ and the Justice Department ${ }^{82}$ to suggest that the rights of secured creditors in reorganization proceedings are not absolute. Several commentators have also understood New Haven as endorsing the uncompensated impairment or sacrifice of a lien in reorganization proceedings if required in the public interest. ${ }^{83}$ It will be argued here, however, that New Haven did not change the law of creditors' rights in reorganization. A public interest formulation of creditors' rights would lead to results inconsistent with the purposes of the reorganization statutes by creating legitimate claims for just compensation against the United States.

\section{A. The Public Interest and New Haven: An Interpretation of the Case}

The ultimate issue in New Haven was the price the Penn Central Railroad was to pay for the assets of the bankrupt New Haven Railroad upon its inclusion in the merged Pennsylvania-New York Central System. ${ }^{84}$ Bondholders of the New Haven contended that the lower court's order of payment of liquidation value as of December 31, 1966 would not compensate them for borrowing and deferments that had resulted in the accumulation of senior claims dating from the inception of the proceedings in $1961,{ }^{85}$ which by 1968 amounted to more than $\$ 70$ million. ${ }^{80} \mathrm{An}$ unspecified portion of that amount was attributable to priority claims accrued before income reorganization was found to be impossible. But that impossibility had become clear at least by December $31,1963 .{ }^{87}$ Therefore, most of the claims derived from operating losses incurred while there was no prospect of income reorganization.

${ }^{80} 399$ U.S. 392 (1970).

${ }^{81}$ See In re Penn Cent. Transp. Co., 384 F. Supp. 895, 922 (Spec. Ct. 1974), motion for leave to file petition for writ of certiorari and/or mandamus and/or prohibition denied, 420 U.S. 922 (1975).

${ }_{82}$ Brief for Appellants at 13, 27-28, Regional Rail Reorganization Act Cases, 419 U.S. 102 (1974).

${ }^{83}$ See Murphy, supra note 18, at 16 \& n.9; YALE NoTE, supra note 18, at 1005, 1011-16.

s4 399 U.S. at 399.

${ }^{85}$ Brief for New York N.H. \& H.R.R. First Mortgage 4\% Bondholders Committee, at 102-09.

399 U.S. at 490.

${ }^{87}$ Id. at 460; Pennsylvania R.R.-Merger-New York Central R.R., 331 I.C.C. 643, 698 (1967). 
The Supreme Court conceded that the continued operation of the railroad during the 1960's "greatly depressed the value of the bondholders' interests," and that "the time consumed in the course of the proceedings in the reorganization court" itself "imposed a substantial loss upon the bondholders." say that "in the circumstances presented by this litigation we see no constitutional bar to that result." Finance Corp. v. Denver \& Rio Grande Western Railroad Co.,$^{90}$ the Court noted that security holders "cannot be called upon to sacrifice their property . . . . But they invested their capital in a public utility that does owe an obligation to the public ... [B]y their entry into a railroad enterprise, [they] assumed the risk that in any depression or reorganization the interests of the public would be considered as well as theirs." "91 Although this language suggests that creditors' rights are not immutable in the face of a strong public interest, the actual holding in New Haven, especially when viewed in light of the secured creditors' previous acquiescence, indicates that the fundamental rule has not changed.

In the Denver \& Rio Grande case, whose language purportedly creates a significant exception to the guarantee of full liquidation value, the Court indicated only that the public interest "justifies . . . requirements for reasonable maintenance and improvement of the properties and for a capitalization with fair prospects for dividends on all classes of securities." ${ }_{92}$ Junior bondholders were seeking to reject a plan because investments undertaken out of current earnings during the trusteeship failed to add to the total valuation of the railroad, while interest on senior claims continued to run, so that the amount of compensation for their claims and their participation in the reorganized enterprise were thereby reduced. ${ }^{93}$ But they did not contend that the liquidation value of their liens was impaired.94 In upholding the bankruptcy court's power to override the rejection

\footnotetext{
399 U.S. at $490-91$.

so Id. at 491 .

328 U.S. $495,535-36$ (1946).

" 399 U.S. at $491-92$,

22328 U.S. at 536.

"s Id. at 515 .
}

"Denver is not inconsistent with the Third Ave. and Jersey Central cases, which indicate that the constitutionally cognizable property right of a secured creditor in the liquidation value of collateral securing a debt, up to the amount of the indebtedness, must be preserved in the conduct of reorganization proceedings. At most, the Denver case may indicate that a secured creditor does not have a comparable vested property right in any excess of value over liquidation value that may accrue to him through reorganization, at least until the effective date of the valuation and plan of reorganization. 
of the plan by the juniors when the plan had been found fair and equitable as to them, the Court was careful to note that the bankruptcy power is "adequate to require creditors to acquiesce in a fair adjustment of their claims, so long as the creditor gets all the value of his lien and his share of any free assets. ${ }^{95}$ So Denver itself reaffirmed the secured creditor's right to the full value of his lien and limited the role of the public interest to justifying investments and maintenance expenditures not impairing lien value..$^{96}$

In contrast to the situation in the Denver case where the railroad's earnings were increasing rapidly during the reorganization proceedings, the New Haven railroad was being kept in operation throughout the proceedings after it had been determined that reorganization on an income basis was impossible. ${ }^{97}$ In fact, the reorganization proceedings were continued primarily for the purpose of allowing the negotiation of a sale of the New Haven assets in bulk. ${ }^{98}$ Such a sale might have been perceived as potentially more advantageous to New Haven creditors than an immediate liquidation sale; certainly, the fact that no bondholder petitioned the reorganization court to dismiss the proceedings in order to permit foreclosure until April 1967, ${ }^{99}$ over three years after reorganization possibilities had dwindled, supports this conclusion ${ }^{100}$ and may indicate the bondholders' strategy.

${ }^{95} 328$ U.S. at 533, citing Wright v. Union Cent. Life Ins. Co., 311 U.S. 273, 278 (1940).

${ }^{96}$ Besides quoting from the Denver case, the Court in New Haven quoted the following language from the Penn Central Merger Cases, 389 U.S. 486, 510-11 (1968): "[P]rivate persons assume the risks attached to their investments," and "[w]hile the rights of the bondholders are entitled to respect, they do not command Procrustean measures . . . . The public interest is not merely a pawn to be sacrificed. . . ." 399 U.S. at 492.

In Penn Central, New Haven bondholders sought to hold up the merger of the Pennsylvania and New York Central Railroads because the two railroads had not agreed, and the I.C.C. had not required them, to be responsible for all of the New Haven's losses in the period before its eventual inclusion in the merged system. However, an interim package of financial support from the Penn Central that would provide sufficient funds to keep the New Haven running had been ordered by the I.C.C.

In these circumstances, the Court relied on the public interest in keeping the New Haven operating to justify rejecting the bondholders' appeal. But the Court was careful to note that the bondholders could litigate the terms of the New Haven inclusion in the reorganization court or on appeal. 389 U.S. at 511. Thus, the case did not redefine the constitutionally protected property rights of secured creditors. See In re Penn Cent. Transp. Co., 494 F.2d 270, 278, 281 (3d Cir.), cert. denied, 419 U.S. 883 (1974).

${ }^{97}$ Pennsylvania R.R.-Merger-New York Central R.R., 331 I.C.C. 643, 698 (1967).

${ }^{83}$ Cf. New Haven Inclusion Cases, 399 U.S. 392, 408-418 (1970); In re Penn Cent. Transp. Co., 494 F.2d 270, 282 (3d Cir.), cert. denied, 419 U.S. 883 (1974).

${ }^{99} 399$ U.S. at $493 \&$ n. 83.

${ }^{100}$ Cf. Brief for Appellee New Haven Trustee at 87, Regional Rail Reorganization Act Cases, 419 U.S. 102 (1974); In re Penn Cent. Transp. Co., 494 F.2d 270, 282 (3d Cir.), cert. denied, 419 U.S. 883 (1974). 
Although the Court in New Haven denied the bondholders' appeal for compensation from the Penn Central, it did not, as earlier cases had not, ${ }^{101}$ sanction a public interest exception to the right of a secured creditor to the liquidation value of his lien. The bondholders failed to show that they had been coerced into permitting the New Haven to continue in operation. ${ }^{102}$ Even if they had been coerced, it would seem that their claim would properly have been against the United States rather than against the Penn Central. ${ }^{103}$ But in any event, the Supreme Court was unable to award compensation because the bondholders had completely failed to show by what amount, if any, their security position was eroded by the New Haven's operating losses and the accumulation of senior claims. ${ }^{104}$

\section{B. The Public Interest Rationale: Its Threat to Creditors' Rights, and the Tucker Act}

Despite the limits of the actual holding in the New Haven case, the opinion's public interest language presents a significant threat to the position of a creditor in corporate reorganization. Read out of context, it seems to inject the public interest factor into the definition of a creditor's essential property right. Thus, the Government argued in the Regional Rail Reorganization Act Cases ${ }^{105}$ that "[t]he question whether involuntary continued loss operations result in a taking cannot be answered by reference to any bright line test. The determination whether a taking has occurred in the course of a railroad reorganization requires a complex balancing of the competing public and private interests." ${ }^{100}$ The special federal court supervising reorganization of railroads in the northeast has gone even further, saying that " $[t]$ he key finding prerequisite to . . . postponement of creditors' remedies is the likelihood of successful reorganization." ${ }^{107}$ This is clearly inconsistent with the constitu-

101 See text and notes at notes $91-96$ supra.

102399 U.S. at 493; cf. In re Penn Cent. Transp. Co., 494 F.2d 270, 278, 282 (3d Cir.), cert. denied, 419 U.S. 883 (1974). But see YALE NOTE, supra note 18, at 1011 n.42, which suggests that the Supreme Court could not have dismissed the bondholders' claim on this ground, and that the Court must therefore have assumed a new constitutional standard, because the ICC and the district court "encouraged the acquiescence."

${ }^{103}$ Cf. Regional Rail Reorganization Act Cases, 419 U.S. 102 (1974).

104399 U.S. at 492-93; Pennsylvania R.R.-Merger-New York Central R.R., 331 I.C.C. 643, 698 (1967); see note 28 supra.

105419 U.S. 102 (1974).

106 Brief for United States as Appellants at 17. The reply brief did not abandon this position, see text at note 109 infra.

117 In re Penn Cent. Transp. Co., 384 F. Supp. 895, 919 (Spec. Ct. 1974), motion for leave to file petition for writ of certiorari and/or mandamus and/or prohibition denied, 420 U.S. 922 (1975); see note 24 supra. 
tional protection of secured creditors' rights that Supreme Court cases since Radford and Continental Bank have recognized. The key finding should be that liquidation value will not be denied to secured creditors.

An expanded role for the public interest factor in reorganization court decisions respecting the security position of creditors may lead to validation of judicial actions that have until now been considered confiscatory. ${ }^{108}$ In its argument in the Rail Act cases, the Government contended that at least "for a reasonable time," pending substantial good faith efforts at rehabilitation, "the claimants against a bankrupt railroad may constitutionally be compelled to bear the burden of continuing its operations in the public interest." 109 This construction of creditors' rights undercuts the property right of a lienholder to the full liquidation value of the lien and is thus in conflict with the rules enunciated in the major judicial decisions in which the rights of creditors were defined. A constitutionally cognizable taking will occur if the value of the collateral falls below the amount of the indebtedness it secures, no new collateral of equivalent value is substituted, and the value of the reorganized or liquidated corporation cannot compensate the creditor for the full liquidation value of his lien. ${ }^{110}$

Despite the interests that may arise in preserving the operations of certain corporate enterprises, such as interstate railroads, bankruptcy reorganization courts must not overlook compelling public policy reasons for permitting foreclosure and withdrawal of capital when liquidation value would be impaired by further delay. ${ }^{111}$ Although it is beyond the scope of this comment to develop fully the economic implications of undermining the property rights of creditors by delaying or attenuating enforcement of security contracts, in general the cost of borrowing would increase and the

I08 See Yate Note, supra note 18, at 1008-16.

${ }^{109}$ Reply Brief for United States as Appellants at 2. But cf. note 119 infra.

110 Rosenberg, supra note 3, at 528-29; cf. In re New York, N.H. \& H.R.R., 147 F.2d 40, 53 (2d Cir.), cert. denied, 325 U.S. 884 (1945). But see In re Yale Express System, Inc., 384 F.2d 990 (2d Cir. 1967).

"11 Several jurisprudential theories of the taking clause support the view that delay in such circumstances would be confiscatory. See Berger, A Policy Analysis of the Taking Problem, 43 N.Y.U.L. REv. 165, 195-98 (1974) (emphasizing protection of recognized economic interests); Dunham, Griggs $v$. Allegheny County in Perspective: Thirty Years of Supreme Court Expropriation Law, 1962 SuP. CT. REv. 63, 80; Sax, Takings, Private Property and Public Rights, 81 YaLE L.J. 149 (1971) (emphasizing protection of non-interfering economic uses). It was argued in YaLE NoTE, supra note 18, at 1018-21, that this theory recognizes a secured creditor's right to withdraw capital from a bankrupt enterprise that cannot operate profitably. 
availability of credit would be diminished for similar investments. ${ }^{112}$ The immediate effect of the changes would be to price certain marginal enterprises out of the credit market, perhaps even denying the possibility to some salvageable enterprises the opportunity of arranging long-term debt obligations to bail themselves out of a current predicament. ${ }^{113}$ But the ultimate economic impact of the restriction of lien enforcement in corporate reorganizations, as one writer has recently pointed out, "goes well beyond such marginal cases . . . . While the contingency of nonenforcement will not affect all potential borrowers equally, since the stronger would just have to pay more for their credit, while the weaker would be denied credit altogether, its effect on the cost of credit, and thereby upon economic growth, is undeniable." 14 These public policy implications have not been totally lost on the judiciary. Justice Brandeis, for example, supported his condemnation of the first Frazier-Lemke Act, which applied only to pre-existing loan contracts, with the observation that its drafters realized that prospective application would wipe our farmers' future mortgage credit. ${ }^{115}$

Thus, the public interest rationale cannot, in view of the long line of applicable Supreme Court decisions, render the uncompensated confiscation of a creditor's property interest constitutional. And even if the precedent mandating the protection of full liquidation value did not preclude a reorganization court from allowing an erosion in the value of the creditor's security that later goes uncompensated, the desirability of such a confiscation as a matter of public policy would be far from clear. In any case, the accommodation of important public interests in both maintaining existing enterprises and fostering a useful market for secured credit should not be undertaken by the reorganization courts on an ad hoc basis. The reorganization statutes were designed to operate without public subsidy. ${ }^{116}$ But if a court were to use the public interest rationale to justify denying a secured creditor his foreclosure remedy, and liquidation value were irreparably lost, the creditor would have a claim for compensation against the United States under the Tucker Act, which vests jurisdiction in the Court of Claims to "render judgment upon any claim against the United States founded . . . upon the Constitution."117

\footnotetext{
112 Cf. R. Posner, Economic Analysis of Law 55, 276 (1972).

is Rosenberg, supra note 3 , at 516.

III Id.

II Louisville Joint Stock Land Bank v. Radford, 295 U.S. 555, 595 \& n.27 (1935).

III Rosenberg, supra note 3, at 537.
}

1128 U.S.C. § 1491 (Supp. III, 1973); see H. Hart \& H. Wechsler, The Federal CourTs 
The availability of a remedy in the Court of Claims is certainly desirable in light of the policy considerations supporting protection of secured creditors and the fostering of a functional credit market. In the Regional Rail Reorganization Act Cases, the Supreme Court approved this remedy for a taking under a special statute that in this context is not distinguishable from chapter $\mathrm{X}$ or Section 77 reorganization procedures. ${ }^{118}$ But Congress directly mandated the continuation of specific railroad operations that threatened a taking in the Rail Act cases, and weighed the public interest considerations (including fiscal considerations) itself. A taking under chapter X or section 77 , on the other hand, would be ordered sua sponte by a reorganization court after only its own view of the public interest had been considered. If a reorganization court uses the Government's public interest interpretation of the New Haven case to impair the liquidation value of creditors' liens, those creditors would be entitled to an award in the Court of Claims despite the fact that the reorganization statutes are clearly intended to be selfsustaining. ${ }^{119}$ Such judicial legislation should be avoided by strict

AND tHe Federal System 1326-30, 1402 (1973); cf. Regional Rail Reorganization Act Cases, 419 U.S. 102, 125-26 (1974).

Since, in connection with the federal power of eminent domain, the constitutional standard "for public use" has been construed as synonymous with a "for public advantage" standard, 2A P. NichoLs, supra note $12, \S 7.2[2]$, at 7-35, and any taking in aid of a constitutional activity has been considered as being "for public use," id. $\S 7.31$ [2], at 7-74 and cases cited, a taking of property in a reorganization proceeding would probably be considered "for public use," in view of the degree of public advantage in reorganizing distressed corporations. See 6 W. CoLLIER, supra note 11, I 0.01. See generally Glidden Co. v. Zdanok, 370 U.S. 530 (1962).

A possible problem in relying on the Tucker Act remedy is that the ultimate judgment of a bankruptcy reorganization court necessarily requires a finding that the plan is "fair and equitable" as to all classes of creditors. See $6 \mathrm{~A}$ W. CoLLJER, supra note 11, $\uparrow 11.06$. For this reason, a creditor might be collaterally estopped from asserting a claim against the United States because by definition there was no taking without compensation. See Yale NoTE, supra note 18 , at $1015 \mathrm{n} .64$. This obstacle would not exist, however, when the reorganization proceeding fails and there is eventual liquidation. In addition, the mutuality of estoppel doctrine is not dead in the federal courts, and the United States would not, in the usual case, have been a party in the reorganization proceeding itself. Therefore, the Treasury is not clearly immune from Tucker Act claims. See 1B J. Moore, Federal Practice 1 T 0.441[2], $0.441[3]$ (2d ed. 1974); $c f$. Blonder-Tongue Laboratories, Inc. v. University of Illinois Foundation, 402 U.S. 313 , 324 (1971).

118 The Court found that Congress had not intentionally withdrawn the Tucker Act remedy that otherwise appeared fully applicable and construed the Rail Act, which was at best ambiguous as to the Tucker Act, so as to avoid holding it unconstitutional in authorizing uncompensated takings. Regional Rail Reorganization Act Cases, 419 U.S. 102, 126-27, 134 (1974). See also In re Penn Cent. Transp. Co., 384 F. Supp. 895, 942 (Spec. Ct. 1974), motion for leave to file petition for writ of certiorari and/or mandamus and/or prohibition denied, 420 U.S. 922 (1975).

119 In its opening brief in the Rail Act cases, the Government argued that the Act was 
adherence to the tests developed in the courts to preserve liquidation value of secured creditors' liens during reorganization proceedings. ${ }^{120}$

\section{CONCLUSION}

Although the remedial rights of a secured creditor can be regulated in the interest of accomplishing successful corporate reorganizations, such regulation violates the fifth amendment of the Constitution when it impairs the liquidation value of the creditor's lien without compensation. This fundamental principle stems simply from the Supreme Court's definition of the secured creditor's property interest and the fifth amendment's prohibition against uncompensated confiscation of property for the public use. The public interest exception that has been drawn from the language of the New Haven Inclusion Cases can certainly never justify the taking of property without compensation. But to the extent that the Tucker Act is relied upon to supply that compensation in confiscatory chapter $\mathrm{X}$ or section 77 reorganizations, the design of the general corporate reorganization scheme is undercut and the function of the Congress in weighing conflicting public interests is usurped. This comment has argued that the reorganization courts instead must respect the absolute property rights of secured creditors and must not employ the public interest rationale to allow the liquidation value of their liens to be diluted during reorganization proceedings.

Martin D. Jacobson

constitutional regardless of the availability of the Tucker Act remedy, but that position was qualified in the reply brief. 419 U.S. at 123 . At oral argument the Solicitor General conceded that availability of the Tucker Act remedy was essential to constitutionality. Letter from Robert H. Bork, Solicitor General, to Professor Edmund W. Kitch, The University of Chicago Law School, March 13, 1975, on file in the office of The University of Chicago Law Review.

${ }^{120}$ One commentator has suggested that the public interest should require that secured creditors' claims be given up in the interest of reorganization and proposes that a tax credit be given to the creditor as compensation. Rosenberg, supra note 3 , at 542 . This suggestion would require legislation, forcing Congress to weigh the value of reorganized enterprises generally against the needs of the public treasury. Congress might well decide that some businesses should fail because they are not economically viable; failure of such businesses has a positive effect on the economy as a whole because other, healthier businesses will be established to take their place, using resources more efficiently. Congress has in fact made these choices on an individual basis (witness the Lockheed Aircraft and Penn Central subsidies and the decision not to subsidize Pan American Airlines), and may want to reserve the public interest choice for itself rather than delegating it to the reorganization courts. 